\title{
Continuing Education: A Family Matter?
}

\section{Vincent Lignon}

Translator. Patrick Hamm

\section{CpenEdition \\ Journals}

Electronic version

URL: http://journals.openedition.org/travailemploi/7649

DOI: 10.4000 /travailemploi.7649

ISSN: 1775-416X

\section{Publisher}

DARES - Ministère du Travail

\section{Printed version}

Date of publication: 30 December 2017

Number of pages: $127-158$

ISSN: 0224-4365

\section{Electronic reference}

Vincent Lignon, "Continuing Education: A Family Matter?", Travail et Emploi [Online], Hors-série | 2017, Online since 11 July 2019, connection on 13 April 2021. URL: http://journals.openedition.org/ travailemploi/7649 ; DOl: https://doi.org/10.4000/travailemploi.7649 


\title{
Continuing Education: A Family Matter?*
}

\author{
Vincent Lignon ${ }^{* *}$
}

\begin{abstract}
Is there a statistical relationship between changes in family status and access to continuing education? This article attempts to answer this question based on an empirical analysis of Emploi en continu (Continuous Employment) surveys conducted in France from 2003 to 2012. While the results show that for women childbirth is associated with a decrease in the likelihood of continuing education, they also suggest that children's entry into the school system provides an opportunity for better educated people to participate more in company training. The formation and break-up of couples are also associated with gender inequalities in access to education: the break-up of a couple is negatively correlated with the probability of attending company training, especially for women who have custody of their children. For education offered by an employment agency, mostly aimed at the unemployed, it seems that what matters most is less the distribution of child custody than the employment status of the partners at the time of the break-up.
\end{abstract}

Tn public discourse, continuing education ${ }^{1}$ is a major tool used by employment policy to cope with rising unemployment and to help make people's career paths more secure (CERC, 2006; SEILliER, 2007). The French system has been reformed several times since the early 2000s, with each reform intended to strengthen the "individualisation" of the right to continuing education and to help make individuals actors who are responsible for their own lifelong learning (DUBAR, 2008). This notion of the

\footnotetext{
* Translation: Patrick Hamm.

Article published in French in Travail et Emploi, no 143, juillet-septembre 2015.

The author wishes to thank Pierre Courtioux, Christine Erhel, Jean-Luc Outin, Corinne Perraudin, Coralie Perez, Anne Solaz, Olivier Thévenon and the anonymous reporters for their comments and remarks that led to improving this article. He retains, however, sole responsibility for any errors that may remain

** At the time Vincent Lignon wrote this article, he was a PhD student at the Centre d'économie at the Sorbonne (CES, University of Paris 1, Panthéon-Sorbonne) and at the Institut national d'études démographiques (French Institute for Demographic Studies - INED). He was also associated with the Edhec Business School. He is now an economist at the Caisse nationale des allocations familiales (CNAF, France's child benefit fund) and is associated with the CES; vincent.lignon@cnaf.fr.
}

1. By continuing education, here is meant all the education undertaken after the completion of a person's initial studies. 
empowerment of individuals (GAUTIÉ, PEREZ, 2010) can be seen particularly in the Act of 4 May 2004, which introduced the individual right to education (droit individuel à la formation - DIF) and, more recently, in the Act of 5 March 2014, which established the personal education account (compte personnel de formation - CPF). ${ }^{2}$

Studies that seek to identify the determinants of access to education are therefore more relevant than ever. To the extent that mechanisms intended to empower people are truly effective only if people actually take ownership of them, it is important to identify any barriers to education as well as the characteristics of people who have the least education. The analysis of the determinants of education has given rise to a large literature, which shows, in particular, that it is those who are most educated and most stable in the labour market who have the highest rates of access (BLASCO et al., 2009; FOURNIER, 2008). Some studies also emphasise that company policies (interviews, dissemination of information, presence of a training manager) play a significant role in the participation of employees (LAMBERT et al., 2009).

In this context, the role of any changes in the parental situation (birth, children's entry into school) or people's conjugal relationship (couple formation or break-up) -which we shall call "family events"- has never been analysed in the case of France. ${ }^{3}$ Focusing on the family determinants of continuing education is nevertheless not without interest. While recalling that precautions are necessary when considering a phenomenon in different national contexts (MAURICE, 1989), it can be noted that, according to Eurostat statistics from 2007, Europeans declare family constraints to be the biggest obstacle to education, ahead of job and financial constraints. ${ }^{4}$ In France, Sébastien Gossiaux and Patrick Pommier (2013) showed that, based on the Adult Education Survey (AES) in 2012, family responsibilities are the obstacle most often cited by individuals ( $34 \%$ of cases). In addition, considering the broader literature on the links between labour supply and family events, many studies point out that births (PAILHÉ, Solaz, 2007), a child's entry into the public school system (MosCHION, 2012; THÉVENON, 2009) and couple break-ups (BONNET et al., 2010) have an important impact on people's career paths and are therefore likely to influence their educational prospects.

The main objective of this article is thus to contribute to the analysis of the determinants of continuing education by examining the specific statistical link that exists in France between changes observed in the family situation and access to continuing education. To do this, we proceed in four stages. First, we provide a theoretical justification

2. One of the objectives of the CPF is to "give everyone the means to develop professionally and to secure their professional career, in particular by raising their qualifications by at least one level during their professional life" (page 11 of the National Interprofessional Agreement [accord national interprofessionnel-ANI] dated 14 December 2013). The CPF makes it possible to accumulate 150 hours of education in a special account (against 120 hours for the DIF), which can be drawn on, at the person's initiative, at any time during their professional career for the purposes of education. Unlike the DIF, the CPF is not attached to the contract but to the person.

3. To our knowledge, in the case of Germany only Harry FRIEBEL (2008) has analysed the impact of births on individuals' further education, based on a field survey.

4. In $2007,36.6 \%$ of Europeans declared that they had given up further education due to family reasons. 
for our interest in family events and calculate the effects that can be anticipated. We then present the database and the method used to conduct our analysis. The results are presented in stage three, based on logistic regressions differentiated by gender and by the type of education (company training/education offered by an employment agency). Finally, we conclude with a few remarks about the nature of this relationship and its implications.

\section{To What Extent can Family Events Influence Access to Continuing Education?}

\section{Family Status and Access to Continuing Education}

There have been relatively few studies on the influence of the parental and conjugal situation of individuals on participation in continuing education in France. It has been recognised that parental activities have a considerable weight in household time schedules (EYDOuX et al., 2006), and it has been observed that people who have children take less part in education than others because of their domestic constraints (FOURNIER, SIGOT, 2009). It is mainly the participation of women in education that is affected by the presence of children in the household (FourniER, 2001; FourniER, SigOT, 2009; FLETCHER, 2002). Indeed, participation in education implies a reorganisation of a person's schedule. In so far as women continue to assume a large share of domestic chores, they are forced to reorganise in one out of five cases when in education, compared to one in ten for men. ${ }^{5}$ In addition to being complicated to manage, reorganising like this can prove costly (childcare fees) and lead women to give up their education (FOURNIER, SigOT, 2009). According to Christine FouRNIER and her co-author Jean-Claude SIGOT (2009), the children's age is also an important factor in access to education. Taking part becomes more difficult when children are young: all else being equal, having children under age 6 reduces the likelihood of accessing education.

As far as we know, there is no specific work on the links between conjugal status and access to education. This question has nevertheless been addressed in the French case by Edwige CROCQUEY (1995), who compared the educational situation of the population of single people with those of married people. She showed that single people engage in more training than the average, although with notable differences by gender. ${ }^{6}$ Between January 1992 and May 1993, 23.5\% of men in couples took part in education, compared with $19.5 \%$ of women in couples. Among single males, $18 \%$

5. These figures were obtained by Christine FouRnIER and Jean-Claude SigOT (2009) on the basis of the survey Formation continue (Continuing Education) 2000 of the French Centre d'études et de recherches sur les qualifications (Centre for Research in Education, Training and Employment - CÉREQ).

6. It must be noted however that, using American data, James A. HeckmAn and Jeffrey A. Smith (1999) came to the reverse result. In this regard, Taylor Shek-Wai HuI and Jeffrey A. SMiтH (2002) emphasise that the studies available on people's conjugal status do not always lead to a consensus when a comparative approach is adopted. 
took part, versus $20 \%$ of unmarried women. CROCQUEY (1995) also pointed out that the reasons that lead single and married individuals to obtain education are different. Free of any family responsibilities, single people may find it expedient to make a radical change in their professional activities: they can then take part in education aimed at enhancing their internal or external mobility (change of post, company). People in a couple, by contrast, are constrained by their situation and instead seek to get education aimed at stabilising their position within their profession (for better working conditions, wages, etc.).

\section{Why Focus on Family Events? Theoretical Framework for an Approach Based on the Life Course}

In the context of the promotion of lifelong learning and the individualisation of the right to education, we have emphasised in the introduction the need to take into account the factors which, during the course of a person's career trajectory, may influence the probability of obtaining further education. In order to analyse the determinants of inequalities in access to education, a theoretical framework that focuses on people's individual course in life would therefore be suitable for an analysis of the determinants of inequalities in access to education. Such a framework is provided by the life course approach (henceforth LCA).

This approach emerged in the 1960s, at the crossroads of a variety of disciplines -sociology, psychology, history, demography and economics (ELDER, 1998). Today it is considered to offer a key perspective for understanding the dynamics of life trajectories (BUTZ, TORREY, 2006). Its main objective is to understand the heterogeneity of individual paths by highlighting the role of institutional determinants (economic environment, social norms, legal framework, etc.) on the positions occupied by individuals during their lifetimes (ANXO, ERHEL, 2008). After undergoing multiple developments, this approach has resulted in a series of common principles and a conceptual map that helps to better understand and describe an individual's path in life (HuTCHISON, 2011).

The life course approach focuses on biographical events, especially when it comes to understanding inequalities in life trajectories (ELDER, 1985). Biographical events correspond to major changes during one's life (loss of employment, birth of a child, health problems, death of a loved one, etc.) that can have significant effects on the short term and the long term through the phenomenon of accumulation (SETTERSTEN, MAYER, 1997). ${ }^{7}$ In this framework, whether or not complete information on individual biographies is available, the analysis of events (i.e. changes in situation) is more relevant than that of "stable" characteristics (i.e. observed at a single time) to understand the interactions between the different positions occupied by individuals during their life course (GIELE, ELDER, 1998).

7. For example, for an individual, the loss of a job potentially translates into an immediate loss of income and can have repercussions, via the phenomenon of accumulation, on future professional transitions, depending on the person's more or less temporary absence from the labour market. 
The analysis we propose adheres to this theoretical framework: the events related to parental and conjugal life are an integral part of the life course, and we are therefore justified in thinking that they play a role on the education followed during a person's career. Our perspective complements the results of FOURNIER (2009) on the unequal access to continuing education according to the number and the age of children. We focus here on more precise elements of parental life by seeking to understand the extent to which the arrival of a new child, the start of institutional childcare (at ages 3 and 6) and the changes in domestic constraints that these imply for men and women are correlated with the likelihood of taking part in continuing education. Our approach also differs from works that have studied the educational practices of single and married individuals. By comparison with CROCQUEY (1995), we try to examine the specific role played by couple's forming and breaking up. These key events in conjugal life involve significant changes in people's temporal and budgetary constraints (immediate loss of income, etc.), which can instantly affect their behaviour with respect to labour supply and participation in education (see below). Finally, in keeping with the aim of the LCA to consider the diversity of individual statuses, our analysis focuses on a broad population: we are interested in individuals regardless of their labour market status, in contrast to FOURNIER (2009), whose work deals only with employees.

\section{Potential Impact of Family Events}

Upstream of our empirical work, here we try to identify potential causal mechanisms in order to show how changes in the family are likely to have an impact on access to continuing education. We cannot specifically test the reality of these mechanisms, but this step provides elements for the interpretation and framing of the statistical analysis carried out in the rest of this article. In order to do this, we rely on the work previously cited (Fournier, Sigot, 2009; FouRnIER, 2001; CroCQuey, 1995) and on articles dealing specifically with the effect of family events on labour supply. ${ }^{8}$

To put forward hypotheses about the role of the formation and break-up of couples, we consider the arguments put forward by Carole BONNET and her co-authors (2010) in their article on the links between break-ups and the professional trajectory. The formation of a couple theoretically has two main economic effects: 1) it loosens the budget constraints on individuals (pooling the income of the partners); and 2) it creates a division of domestic tasks that can free up extra time for individuals. In this context, the formation of a couple can potentially have a positive influence on access to education insofar as it allows the freeing of time slots that can be used for education and reduces the financial constraints on individuals, thereby favouring the take-up of training that can prove costly to follow (DuboIs, Fournier, 2014; Gossiaux, POMmier, 2013). By

8. Although the supply of labour and participation in education do not correspond exactly to the same logic, continuing education has close links with an individual's professional situation (DUBAR, 2004). Not only does it depend on positions in the labour market but it is also a means for people to accumulate human capital in order to boost their wages or adapt their skills to a specific position within the framework of re-entry into the world of work. 
considering the inverse arguments, we could assume that a break-up will have the opposite effect. The role played by a break-up may nevertheless depend on the individual's own resources. If these are low at the time the couple breaks up (for example, someone who is unemployed), we might think that the individual will be induced to obtain education so as to boost their wages or to be able to present themselves on the job market with a higher level of human capital. The impact of the formation or break-up of a couple may also vary depending on the division of custody between the former partners: individuals who separate and retain custody of their children must devote more time to domestic tasks, which is an obstacle to their participation in further education. Finally, due to specialisation in practice in the partners' roles within the couple, changes in the individuals' conjugal situation may have gender-differentiated effects. Under the "Monsieur Breadwinner" model, ${ }^{9}$ couples might limit women's access to education, with the opposite effect for men. Conversely, a break-up may free up time for women to take part in education, and be an additional constraint for men who no longer enjoy the benefit of their partner doing the household chores.

Given the results obtained by FOURNIER $(2009,2001)$, it is likely that the arrival of a new child in the household is associated with a decrease in the probability of further education, especially for women. If one takes a more general interest in the theoretical literature on labour supply, the birth of a child has two effects: 1) an income effect due to the fact that the child consumes a share of the household income (comparable to a decline in wage income), which encourages individuals to increase their participation in the labour market; and 2) a substitution effect related to the cost of external child care that may lead to withdrawal from the labour market. Individuals are then confronted with the following trade-off: to work to compensate for the cost arising from children (consumption, etc.) or to stop their professional activity in order to save the cost of childcare. This trade-off is closely linked to the division of domestic tasks between women and men. Indeed, several empirical studies show that the arrival of a child is detrimental to women's careers (interruption of activity and wage reduction) while its effect on men is small or even positive (Meurs, PonthIEuX, 2000). The persistence of the "Monsieur Breadwinner" model is the main explanation for these inequalities, ${ }^{10}$ with the women with the least education being the ones who are most disadvantaged (PAilHé, Solaz, 2007). By analogy, it can be assumed that, in tandem with a birth, men may have more recourse to training to strengthen their position on the labour market (reintegration for those not in work, promotion for those in employment) and thus increase the household income. Given their role in the family, the opposite effect can be envisaged for women, ${ }^{11}$ especially those with the lowest initial levels of education.

9. This model refers to gender specialisation within the couple: women tend to perform the domestic tasks while the role of men is rather more to guarantee the household income (BARRÈRE-MAURISSON et al., 2001).

10. The birth of a child requires adjustments that in most cases depend on the women.

11. In the case of Germany, FRIEBEL (2008) observes that men declare that they turn more to further education to boost their income when a child is born. In contrast, women say that they do not have enough time to take part in education when they are confronted with this event. 
The assumption of the care of children from a certain age (entry into kindergarten or primary school) may also influence educational practices and account for the fact that the younger the children, the lower the likelihood of access to education. In the literature on labour supply, some authors (THÉVENON, 2009; ANXO et al., 2007) point out that children's entry into school is positively correlated with people's job activity (especially women's) by reducing the family constraints and the costs associated with childcare (decreased substitution effect). ${ }^{12}$ It can thus be assumed that children's entry into kindergarten or primary school leads to greater participation in continuing education. It is nevertheless conceivable that this event does not have the effect anticipated. It could create new constraints (driving children to school, etc.) or not offer sufficient compensation with respect to the time available (CROCQUEY, 1995). In addition, it may have no effect on people in employment, who must already have found childcare arrangements, except if the education takes place outside working hours, i.e. in 15\% of cases according to GossiauX and POMMIER (2013). ${ }^{13}$ As in the case of childbirth, it is possible there will be differentiated or contrary effects according to sex and educational level. Indeed, on the issue of pre-schooling, Julie Moschion (2012) shows that children's entry into public childcare has only a weak impact on the supply of labour and affects only women with a higher education who have more than two children. The effect on fathers' labour supply is positive, but with a limited magnitude, as their labour force participation rate is already very high.

The hypotheses that we have formulated are not exhaustive and should be considered as the interpretative pathways that we will follow when presenting our empirical results. Moreover, the analyses presented here mainly follow an individual entry, from the point of view of the supply of labour. Participation in continuing education is, however, heavily influenced by the agreement and willingness of education providers (companies, employment agencies, etc.), which thus indicates the need for studies that take stock of the role of other actors in the field of vocational education (e.g. with matched employer-employee data). However, regardless of the educational opportunities offered by companies but based on their family constraints and their life plans, individuals have a certain latitude in accepting or refusing such education and to carry out (or not) the steps needed with their company or employment agency in order to obtain further education.

12. For example, women who have stopped working after birth expect to return to work once their child reaches three years of age (MÉDA et al., 2003).

13. It is possible, however, that even if education takes place during working hours, it is not held in the usual workplace where the person carries out their activity, thus involving significant adjustments (travel time, etc.). By way of indication, according to Gossiaux and Pommier (2013), 16\% of cancellations are due to the remoteness of the educational site. 


\section{Source and Method}

While changes in the family situation and access to continuing education are likely to be linked, it is still necessary to prove this empirically. The aim of this section is to present the source that we draw on to obtain information about people's participation in education and the family events that they are experiencing, as well as the empirical method that we use.

\section{Use of the Emploi en continu Surveys from 2003 to 2012}

Several sources focus on the participation of individuals in continuing education. The most commonly used are the Formation et qualification professionnelle (Training and Professional Qualification) surveys (FQP 1964, 1970, 1977, 1985, 1993 and 2003) and the Formation continue (Continuing Education) surveys (FC 2000 and FC 2006). ${ }^{14}$ While these surveys provide accurate information about education (educational activities, people's perceptions, etc.) and people's family situations, the number of observations making up their sample seems insufficient to cross-tabulate these two relatively rare events, i.e. family changes and access to education. ${ }^{15}$

In this article, we make use of an original survey on this subject: the Emploi en continu survey (Continuous Employment - EEC). The EEC has been carried out by France's National Institute of Statistics and Economic Studies (Institut national de la statistique et des études économiques - INSEE) since 2003 and is published annually. Its sample is representative of individuals over age 15 living in metropolitan France. This is a rotating sample that is renewed by one-sixth each quarter: individuals in a surveyed residence are interviewed for six consecutive quarters. ${ }^{16}$

In order to undertake our analysis, we compiled the available EECs for the period 2003-2012. This compilation of survey waves has two major advantages for the issue at hand. First, it makes it possible to reconstruct the individual pathways during the surveys and to put in perspective the educational activities and the family events experienced by each person. Second, in contrast to the $F Q P, F C$ and $A E S$ surveys, the nine-year time horizon of the 2003-2012 EECs can be used to identify relationships that are not limited to a given year, are therefore not dependent on a specific situation, and are based on a large number of observations.

\footnotetext{
14. Studies that have made use of these sources include Blasco et al. (2009) and CROCQUEY (1995) for the $F Q P$, and LAmbert et al. (2009), Fournier $(2001,2008,2009)$ and PereZ and Thomas (2005) for the FC 2000 and FC 2006. More recently, the Adult Education Survey has taken over from the $F C$ surveys. This constitutes a new source on continuing education that is in line with the Adult Education Survey 2011-2012 conducted by Eurostat.

15. The $2006 F C$ survey covers 16,500 individuals, the $F Q P$ nearly 40,000 individuals and the $A E S$ survey 14,000 individuals, which seems relatively poor, given that the elements we analyse concern only a small fraction of the population, in particular changes in marital status (see below).

16. For example, an individual interviewed for the first time in the first quarter of the $2007 E E C$ will, if they do not leave the residence, be re-interviewed in the 2nd, 3rd and 4th quarters of 2007, and in the 1 st and 2nd quarters of the 2008 EEC.
} 
To compare family events and access to continuing education, we chose to use the largest possible observation window (see below) for the individuals in our estimates, i.e. fifteen months. ${ }^{17}$ Concerning this point, we formulate the hypothesis that the interrelations between continuing education and family transitions are part of the ongoing organisation of people's schedules, and we assume the existence of anticipatory effects (education upstream of a birth or break-up in order to boost wages, etc.). A window limited to three months or six months seems therefore too limited to identify the relationships that we are seeking to highlight. ${ }^{18}$ In our sample, we therefore keep only individuals who have participated in the six EEC interviews. ${ }^{19}$ Our analyses focus more precisely on all individuals aged 18 to 54 who have completed their initial education for more than one year. Indeed, we are trying to stay consistent with our theoretical approach, which is intended to take account of the diversity of positions that individuals can occupy (in or out of work). Since family events are relatively rare for older individuals, we prefer to exclude them from our analysis. ${ }^{20}$ So by focusing on the study population, we have a database of 158,114 individuals ( 81,705 women and 76,409 men).

Using this basis, we seek to determine whether individuals experienced a change in their marital or parental status during the 15 months surveyed and whether they took part in education (see box). We identified the following family events: couple formation, break-up, ${ }^{21}$ birth of a child, exit of children from very early childhood (transition to age 3 ) and exit of children from early childhood (transition to age 6). In the $E E C$, while there is no variable on the child's entry into the education system, we use information on children's age as a (partial) indicator of their entry into kindergarten and primary school. In our sample, over the period as a whole and for everyone aged 18 to 54 , the formation or break-up of couples (each) affected $1 \%$ of people, births $5.3 \%$, exits from very early childhood $6.4 \%$ and exits from early childhood $6.7 \%$. Apart from an underestimation of the proportion of conjugal events related to the constitution of our sample (see below), the figures we obtained, especially on age-specific fertility rates, are consistent with the vital statistics of the INSEE (BEaUMEL, Pla, 2012).

We also distinguish between two types of education: "company" training and education offered by an employment agency. ${ }^{22}$ While the 2003-2012 EECs can be

17. While it is theoretically possible to reconstruct educational training pathways over 18 months using retrospective information, this is not the case for all variables (notably family variables).

18. Note that using a 12-month window does not modify the estimated coefficients much.

19. Some individuals do not respond to the six interviews because they have left the residence or were partially questioned during the EEC years not available (2013 in particular). We exclude them from our database knowing that their characteristics (especially age) may differ from those of the individuals we have kept (see Appendix, Table A1). 20. Beyond age 54 , fewer than $0.04 \%$ of individuals are affected by a birth. The same applies to people whose children reach age $3(0.1 \%)$ or age $6(0.13 \%)$.

21. In accordance with our hypotheses (cf. above), we also try to identify the status of the partner at the time the couple forms or breaks up (in or out of employment) and whether the individual keeps custody of the children following a break-up.

22. We exclude from the analysis two categories of education that can be identified from the EEC: the CIF (Congé individual de formation - Personal Educational Leave), for which there are too few observations, and educational courses taken in a personal capacity and not financed by the employer, as it is difficult to identify the institutional arrangements with certainty (resumption of non-financed studies, informal education, etc.). The two types of education 
used to differentiate more than two types of education, the modalities of the "type of education" variable vary from year to year. ${ }^{23}$ We therefore had to make a trade-off between limiting the sample to the years for which the definitions of the "type of education" variable are stable and on the other hand retaining a broad time horizon by constructing education variables that could be exploited over the period 20032012. Out of concern for the robustness of the results (broad time horizon, number of observations), we chose the second option, and then opted for a classification of education that was as consistent as possible. Company training and education offered by an employment agency, as we define them, in practice target clearly differentiated audiences in terms of their relationship to vocational training (people in employment/ not in employment). They also refer to distinct objectives (adaptation to the job for the first/re-integration into employment for the latter) and diverge strongly in terms of duration (see box). In our sample, the rate of access to company training was close to $23 \%$, while the rate of access to education offered by an employment agency was $2.3 \%$. These proportions cover all individuals (private and public employees, unemployed, self-employed and inactive) between the ages of 18 and 54 who have completed their initial education: they might therefore differ from the quantities provided by certain studies. $^{24}$

Before discussing the analytical method, note that there are two main limitations to the use of the $E E C$. First, this source is not as accurate on the education variables as the $F C$ and $A E S$ surveys (for example, the $E E C$ cannot be used to identify the need for a re-organisation, the presence or absence of an interview in preparation for education, etc.). To overcome this shortcoming, where necessary we draw on studies that used these surveys in order to clarify our results. ${ }^{25}$ Second, we have made a special selection within our database: by selecting only those people responding to the six interviews, we have excluded by definition those who move when they split up or become partners. ${ }^{26}$ On this point it is nevertheless important to note that there is no reason to think that the education practices of the people we have excluded differ significantly from those we have retained. ${ }^{27}$

that are included in our analysis nevertheless account for almost $80 \%$ of the educational courses completed by people aged 18 to 54 who have completed their initial education for more than one year.

23. Cf. see Appendix, Table A2.

24. In particular, the results from the 2006 FC survey that focus on employees aged 18-64. If we retain a field similar to that survey, our results are similar. Likewise, the access rates we obtain are consistent with those that can be calculated for these educational categories using administrative sources (DIRECTION DU BUDGET, 2013).

25. In particular those by Gossiaux and POMMIER (2013) and FourNIER (2009).

26. This selection leads to an underestimation of the share of conjugal events. Based on calculations of the aggregate share of individuals in couples at each age, it is possible to estimate an annual rate of couple formation that would not be affected by this selection. To provide an order of magnitude, this rate can be estimated as ranging from $1.5 \%$ to $2 \%$ of the population over age 18 (compared with $0.8 \%$ for the $E E C$ ).

27. By controlling the individuals entering the EEC in the course of the survey (i.e. individuals who moved into an area of the survey), it can be seen that people who move have higher access rates than the others and are more subject to job mobility. While the causes of their moving are not known, this gap basically conceals an age effect. By controlling for age, the difference in the rate of access to education between the two populations becomes low (10.67\% of those aged 18-54 who move take part in education during the quarter versus $10.01 \%$ of those who do not move). 


\section{Box \\ Construction of the Variables on Continuing Education and Family Events in the $E E C$}

\section{Reconstructing Individual Education Episodes during the Fifteen Months of the Survey}

To reconstruct the episodes of education, we used the variables FC5D "Have you taken part in education in the last three months?" and FORTYP "What kind of education have you had in the past three months?" of the EEC. We retained people who participated in the six survey interviews and determined, for each of these interviews, whether or not they had access to education and the type of programme in which they participated. We compiled this information and determined a fifteen-month education pathway for each individual.

\section{The Types of Education Taken into Account}

Corporate Training (FENTR): we included in this category the education offered by the employer, which can be identified in all the EECs for the period 2003-2012. These education courses are generally grouped under the term "training plan". Financed directly or indirectly (through industry collection agencies) by the employer, they aim to ensure the employees' adaptation to their workplace and the development of their skills. These are generally of short duration (30 hours in 2009 according to French tax declaration 2483) and aim at internal mobility (CYTERMANN, WANECQ, 2010). As of 2007, we also included the individual right to education (DIF) in this category. Indeed, while the DIF is a programme based on individual initiative, it is noteworthy that it is generally used within the framework of the courses provided for by the training plan. ${ }^{1}$ On the basis of the 2006 FC survey, we estimated that $48 \%$ of the DIFs were initiated by the employer, to which may be added $38 \%$ which, while of course being followed by the employee, fall within the framework of training already set out by the employer. Furthermore, the DIF is only made partial use of by employees (6.5\% of employees made use of it in 2010 according to the 2012 French Budget Act, with an average duration of slightly more than 20 hours), which suggests that this programme does not amount to much more than a "formal" right: its existence "does not fundamentally alter industrial relations" (DESCAMPS, 2012, p. 4).

Education offered by an employment agency (FPLAC): this is primarily aimed at jobseekers and is intended to prepare for a re-entry into the labour market. These programmes are lengthy and are mainly financed by public funds.

The FENTRs and the FPLACs are aimed at different audiences: $99.1 \%$ of people who access an FENTR are employed and 79.29\% of those who register for an FPLAC are unemployed or inactive. Although the variable for education duration in the $E E C$ is poorly filled in and not well suited to individual analysis, it is noteworthy that, on average, the FENTRs last 34 hours and the FPLACs 198 hours.

1. In his speech of 16 October 2013 on the personal education account, the then Minister of Labour, Michel Sapin, refers to this substitution: "[The personal education account] must not get bogged down in the same pitfalls as the DIF. The DIF did not receive dedicated funding. The programmes initiated in this context were all too often actions that fell within the training plan [at the employer's initiative]. The personal education account must have specific financing so as not to be undermined and relegated to other measures" (Source: http://discours. vie-publique.fr/notices/133002401.html; accessed 27 November 2015). 
Identifying the Occurrence of Family Events during the 15 Months of the Survey

Couple formation, break-up: to identify changes in individuals' conjugal situation, we compared the individual conjugal situation (COHAB variable: "Do you live as a couple?") for each interview. When these events occur, we identified the current employment status of the partner (i.e. at the time the couple forms or breaks up) using the household identifier (IDENT) and the partner's identifier (NOICON). While the EEC does not provide an accurate picture of how childcare is distributed, it does make it possible to determine whether the children are still living in the residence after any break-up. In this framework, we tried to identify whether the individual retains custody of children under age 6 following a break-up using the variables EM1 (presence of the person's children in the residence) and NBENF6 (number of children under age 6 in the residence). In our sample, $75 \%$ of women have custody of their children after a break-up, which is close to the figure found by Arnaud RÉGNIER-LOILIER (2013), who estimates that in 7 out of 10 cases, custody is accorded to the mother.

Childbirth: it is not possible in the EEC to distinguish a birth from the new presence in the home of the partner's child. We therefore assumed that the time devoted to the child is the same in both cases. We identified a birth when the number of children under 18 months of age in question $\mathrm{N}$ is greater than the number of children under 18 months of age in $\mathrm{N}-1$. To capture situations where a child is born and another child reaches 18 months, we checked the number of children under age 3.

Exit of children from very early childhood and from early childhood: we calculated the number of children under age 3 and under age 6 for the six interviews. If the number observed at interview $\mathrm{N}$ is less than the number observed at $\mathrm{N}-1$ (except where there is a birth), we created an exit indicator from very early childhood or from childhood.

\section{Method of Analysis}

Our strategy is to estimate logistic models that, "all else being equal", explain the probability of accessing continuing education over the 15 months of observation based on the occurrence of family events during this period. Taking into account the factors discussed above, we made estimates broken down by sex and type of education (company training/education offered by an employment agency). Similarly, in light of the assumptions we have made, several cross-tabulations were estimated for family events. A first model (model 1) differentiates between conjugal events (couple formation, break-up) according to the partner's professional situation and events related to the parental situation (birth, exit from early or very early childhood), according to the educational level (French high school baccalauréat diploma ${ }^{28}$ or lower/higher education diploma). A second model (model 2) introduces a cross-tabulation between break-ups and the fact that the individual does or does not have custody of children

28. The approximate equivalent of British A levels. 
under the age of $6 .^{29} \mathrm{~A}$ third model (model 3) cross-tabulates break-ups with the partner's situation at the time of the break-up and the custody of children under age $6 .{ }^{30}$

The estimates are controlled by several classical determinants of access to education: age, level of education, occupational status (a dimension crossing status of activity, seniority, working time and contract), socio-occupational category (SOC), sector of activity, size of institution, ${ }^{31}$ country of birth, unemployment rate in the region of residence, ${ }^{32}$ and family status (crossing parental status, conjugal status and spouse status). These variables correspond to the individual's position at the first interview. We also controlled for any professional transitions that might occur during the observation window that could affect the likelihood of continuing education, such as changes in function or employer and loss or resumption of employment.

As we have pointed out, corporate training and education provided by an employment agency are indicative of the type of the target beneficiary (see box). In fact, a breakdown by status of activity (active, unemployed, etc.) does not appear to be relevant: by estimating regressions by activity status (individuals in work/individuals out of work at the first interview), we note that the coefficients vary little with respect to regressions by the type of education, especially for family events (the correspondence between the type of education and the activity status seems to be respected); furthermore, in contrast to a breakdown by activity status based on the position of individuals at the first interview, estimating our regressions by the type of education makes it possible to identify indirectly individuals' occupational status at the time of education.

It is worth noting the potential postponements of educational activities that we cannot a priori capture from our observation window: women who become mothers and withdraw from the labour market are likely to postpone their education project to a later time at which they will consider re-entering the labour market. However, if the effects of postponements exist and coincide with children's entry into kindergarten or primary school, our regressions allow us to identify them in part through the effects of "exits from very early childhood" and "exits from childhood". 33

Overall, our estimates are based on assessing whether education in the 15 months of observation is significantly associated with a change in the family situation in the

29. We chose to focus on children under age 6 because the domestic constraints are particularly great in the presence of young children (FOURNIER, 2009).

30. For models 2 and 3, the variables on the formation of couples and the events related to the parental situation are identical to those in model 1.

31. For the inactive and the unemployed, the SOC, the sector of activity and the size of the establishment correspond to those of the last job held.

32. Imputed by year and quarter of the interview based on INSEE data on localised unemployment rates.

33. Individuals with a child reaching age 3 or 6 have in reality been affected by an earlier childbirth. The same type of argument is advanced by ANXo et al. (2007) who study, using the framework of the life course approach, the links between employment behaviour and the family situation on cross-sectional data. To capture the diversity of positions occupied by individuals in the course of the trajectory and their effect on the labour supply, their strategy was to use cross-cutting categories that correspond to "key" phases in life: life as a single person, couple without child, couple with child, separated with child, etc. 
same period, beyond the effects transmitted by the various determinants of continuing education and while differentiating our regressions by gender and by type of education. In the next section, we present the results that we obtained.

\section{Results}

As our theoretical and empirical framework suggests, our estimates show that changes in family status and access to education are correlated, "all else being equal". In accordance with our hypotheses, we highlight the coefficients differentiated by gender and by type of education.

Before fleshing out these general remarks, note that the results obtained on the "classical" determinants are consistent with those in the literature (in particular BLASCO et al., 2009; LAMBERT et al., 2009; FOURNIER, 2008). ${ }^{34}$ For example, in the case of company training, we observe that the highest probabilities of access concern graduates of higher education, those with the most stable employment status, managers and the intermediate professions, large corporations and the energy and finance sectors (see LAMBERT et al., 2009). As in CROCQUEY (1995), we observe that being a parent and in a couple is associated with a decrease in the probability that women access continuing education. Conversely, fathers in a couple with a child seem to be more involved in education. Given the number of observations available in our sample, we can also specify certain correlations, in particular those relating to the level of education. The empirical literature on participation in education shows that the effect of the diploma is not strictly hierarchical in the sense that the coefficients associated with the "baccalauréat +2 " category are higher than those for "BAC +3 and higher" ${ }^{35}$ The more in-depth analysis permitted by the $E E C$ reveals that, among the "BAC +2 ", it is the holders of a BTS, a DUT/DEUST ${ }^{36}$ or a paramedical diploma (for women only) who are more likely to have access to company training than holders of a bachelor's degree, a BAC +4 or a business school diploma. Finally, our estimates show a strong relationship between occupational transitions and access to education: while integrating a job or changing a job is positively correlated with access to company training (job training, etc.), the loss of a job is associated with a significant likelihood of accessing education offered by an employment agency.

In order to make a specific analysis of the influence of family events, we first focus on the role of the formation and break-up of couples and, second, on changes in people's parental situation. A third sub-section discusses the causal meaning of our results.

\footnotetext{
34. Cf. see Appendix, Table A3.

35. See, for example, BLASCO et al. (2009).

36. BTS: brevet de technician supérieur (advanced technician's certificate); DUT: diplôme universitaire de technologie (university technology diploma); DEUST: diplôme d'études universitaires et techniques (university science and technical diploma).
} 


\section{Change in Conjugal Situation and Access to Education}

With respect to company training (Table 1), our estimates show that the formation of couples is positively correlated with the likelihood of access to education, but only when the new partner has a job. This is true regardless of the sex, with odds ratio of 1.5 for women and 1.38 for men. Given the non-significance of forming a couple with an unemployed partner, one might think, in relation to the hypotheses that we have

\section{TABLE 1 - Changes Regarding the Conjugal Situation and Access to Company Training during the 15 Months of Interviews (Results from Binomial Logistic Regressions ${ }^{(1)}$ )}

\begin{tabular}{|c|c|c|c|c|c|}
\hline \multicolumn{3}{|c|}{ Women } & \multicolumn{3}{|c|}{ Men } \\
\hline Coefficient & $\begin{array}{c}\text { Std } \\
\text { deviation }\end{array}$ & $\begin{array}{l}\text { Odds } \\
\text { ratio }\end{array}$ & Coefficient & $\begin{array}{c}\text { Std } \\
\text { deviation }\end{array}$ & $\begin{array}{l}\text { Odds } \\
\text { ratio }\end{array}$ \\
\hline
\end{tabular}

Cross-tabulation with the partner's situation (model 1)

No couple formation (reference)

Couple formation, employed partner
$0.40 * * *$

0.11

1.50

$0.32 * * *$

0.11

1.38

Couple formation, unemployed partner

$\begin{array}{llllll}-0.02 & 0.20 & 0.98 & -0.22 & 0.15 & 0.81\end{array}$

No break-up (reference)

Break-up, employed partner

0.01

0.10

1.01

$0.30 * * *$

0.10

1.35

Break-up, unemployed partner

$-0.34$

0.21

0.71

$0.44 * *$

0.18

1.56

Cross-tabulation with custody of children under age $6^{\mathrm{A}}$ (model 2$)$

No break-up (reference)

Break-up, without custody

$\begin{array}{lll}0.07 & 0.10 \quad 1.07\end{array}$

$0.37 * * *$

0.09

1.45

Break-up, with custody

$-0.66 * * *$

0.23

0.52

$-0.32$

0.39

0.73

Cross-tabulation situation of partner and custody of children under age $6^{\mathrm{A}}$ (model 3 )

No break-up (reference)

Break-up, employed partner, w/o custody

0.15

$-0.60 * *$

with custody

Break-up, unemployed partner, w/o custody

Break-up, unemployed partner, with custody

Number of observations

$-0.23$

$-0.87 *$
0.11

1.16

$0.35^{* * * *}$

0.11

1.42

$-0.60 * * \quad 0.26$

0.23

0.51

0.42

0.55

$-0.42$

0.42

81,705

$\begin{array}{lll}0.80 & 0.44 * * & 0.18\end{array}$
*** significant at the $1 \%$ threshold; ** significant at the $5 \%$ threshold; * significant at the $10 \%$ threshold.

${ }^{(1)}$ The full results of these estimates are available upon request from the author.

${ }^{\text {A }}$ The coefficients concerning the formation of the couple are not reported because they correspond to those of model 1.

Interpretation: Beyond the effects of the control variables, women who enter into a couple with an employed partner have a higher probability of participating in company training than women who do not enter a couple (odds ratio of 1.5).

Control variables introduced into the estimate: age, level of education, employment status, SOC, sector of activity, size of establishment, occupational mobility, country of birth, regional unemployment rate, family situation, birth and exit of children from very early childhood and early childhood (variables cross-tabulated with the diploma).

Field: Individuals aged 18 to 54 who have completed initial education more than a year earlier.

Source: Emploi en continu 2003-2012 surveys (INSEE), author's calculations. 
previously posited, that the relationship between the couple formation and access to continuing education depends more on the reduction of the budgetary constraint due to the pooling of income within the household than on the sharing of time between the partners.

If we look at the correlations between the break-up of a couple and access to company training, we note that men who separate from an employed partner are 1.35 times more likely to have access to education than those who do not separate, and they are 1.56 times more likely if the partner is unemployed at the time of the break-up. For women, the coefficients of the variables cross-tabulating break-up and the partner's situation are not significant. These results may reflect the fact that men in break-ups are only rarely granted the weekly custody of the children (RÉGNIER-LOILIER, 2013): this event may, despite an additional income constraint (fixed costs linked to decohabitation, any compensatory alimony), free up time available for education, regardless of the partner's status. The cross-tabulations that we conducted between the break-up of the couple and custody of the children seem to confirm this hypothesis. They show that women who separate and obtain custody of children under the age of 6 have a lower probability of accessing education (compared to the benchmark). Conversely, for men, separating and not keeping custody of the children increases the chances of participating in company training. If the "break-up" event is differentiated according to these two variables (custody and partner's status), it can be seen that the sign and the significance of the coefficients associated with custody of the children persist regardless of the partner's status. This result suggests that the correlations observed between break-up and participation in company training are more interpretable from the point of view of the custody arrangements after the break-up than from the status of the former partner. Keeping custody of the children would therefore be a determining factor in participation in continuing education, as it reinforces the domestic and parental constraints on the individuals (e.g. an obligation to reorganise to take part in education, etc.).

The results obtained for education offered by an employment agency vary considerably from those in Table 1. This is due to the specific characteristics of these educational programmes, most of which involve out-of-work individuals and are aimed at re-integration into the labour market. While entering a couple does not have a significant effect on women, it is noteworthy that men who form a couple with an employed woman have a low probability of taking part in education offered by an employment agency. This result is related directly to the issue of endogeneity (see below): it is consistent with the idea that attractiveness in the marriage market depends on a person's occupational situation (stability in employment, etc.), in particular for men (EKERT-JAFFÉ, SOLAZ, 2001). It can therefore be assumed that the men who are most likely to marry a woman in employment are less likely to take part in education that is aimed primarily at jobseekers.

Table 2 shows a correlation between the break-up of a couple and participation in education offered by an employment agency, but only if the partner is employed at the time of the break-up: individuals who separate from an employed partner are more 
likely to participate in this education than those who do not separate (1.53 times more likely for women and 1.77 times more likely for men). These results are in line with those of BONNET et al. (2010) on the supply of labour. The separation of an employed partner is likely to lead to a significant drop in the standard of living for inactive and unemployed individuals whose own resources within the couple are weak. The latter can then be encouraged to re-enter the job market in order to prop up their income

\section{TABLE 2 - Changes Related to the Conjugal Situation and Access to Education Offered by an Employment Agency over the 15 Months of Interviews (Results from Binomial Logistic Regressions ${ }^{(1)}$ )}

\begin{tabular}{lcc}
\hline \multicolumn{3}{c}{ Women } \\
\hline Coefficient & $\begin{array}{c}\text { Std } \\
\text { deviation }\end{array}$ & $\begin{array}{c}\text { Odds } \\
\text { ratio }\end{array}$
\end{tabular}

\begin{tabular}{lcc}
\hline \multicolumn{3}{c}{ Men } \\
\hline Coefficient & $\begin{array}{c}\text { Std } \\
\text { deviation }\end{array}$ & $\begin{array}{c}\text { Odds } \\
\text { ratio }\end{array}$
\end{tabular}

Cross-tabulation with the partner's situation (model 1)

No couple formation (reference)

Couple formation, employed partner

0.30

0.67

$-1.34 * * *$

0.48

0.26

Couple formation, unemployed partner

0.28

1.49

0.31

0.29

1.36

No break-up (reference)

Break-up, employed partner

$0.49 * *$

0.21

1.63

$0.57 * *$

0.29

1.77

Break-up, unemployed partner

0.29

0.33

1.33

0.38

0.43

1.46

Cross-tabulation with custody of children under age $6^{\mathrm{A}}$ (model 2 )

No break-up (reference)

Break-up, without custody

$\begin{array}{ll}0.74 * * * & 0.20 \\ -0.53 & 0.44\end{array}$

2.10

0.37

0.26

1.44

Break-up, with custody

$-0.53$

0.44

0.59

$1.70 * * *$

0.61

5.47

Cross-tabulation situation of partner and custody of children under age $6^{\mathrm{A}}$ (model 3 )

No break-up (reference)

Break-up, employed partner, w/o custody

$\begin{array}{cccccc}0.86^{* * * *} & 0.23 & 2.36 & 0.36 & 0.32 & 1.43 \\ -0.52 & 0.50 & 0.60 & 1.81^{* * * *} & 0.62 & 6.09 \\ 0.50 & 0.36 & 1.65 & 0.39 & 0.43 & 1.48 \\ -0.57 & 0.89 & 0.57 & -6.93 & 132.69 & 0.00\end{array}$

Break-up, employed partner, with custody

***significant at the $1 \%$ threshold; **significant at the 5\% threshold; *significant at the $10 \%$ threshold.

${ }^{(1)}$ The full results of these estimates are available upon request from the author.

${ }^{\text {A }}$ The coefficients concerning the formation of the couple are not reported because they correspond to those of model 1 . Interpretation: Beyond the effects of the control variables, men who enter a couple with an employed partner have a lower probability of participating in education offered by an employment agency than men who do not enter a couple (odds ratio of 0.26 ).

Control variables introduced into the estimate: age, level of education, employment status, SOC, sector of activity, size of establishment, occupational mobility, country of birth, regional unemployment rate, family situation, birth and exit of children from very early childhood and early childhood (variables cross-tabulated with the diploma).

Field: Individuals aged 18 to 54 who have completed initial education more than a year earlier.

Source: Emploi en continu 2003-2012 surveys (INSEE), author's calculations. 
(BONNET et al., 2010) and, if necessary, to participate in education offered by an employment agency in order to prepare their re-integration into the labour market as well as possible. This relationship between a separation and access to education offered by an employment agency, however, seems to be conditioned on factors relating to childcare: the positive influence of the break-up of a couple formed with an employed person is observed only for women who do not obtain custody of their children and men who, on the contrary, do have custody of them. For the former, it can be supposed that the weight of domestic constraints in the case of custody of the children does not allow them to engage in education. In a logic close to the model of "Monsieur Breadwinner", men who are entrusted with child custody can on the contrary take part in education in order to resume an activity and ensure a certain standard of living for their children. ${ }^{37}$

\section{Change in Parental Situation and Access to Education}

The results of Tables 3 and 4 make it possible to supplement those of FOURNIER (2009). In general, it appears that events relating to the parental situation, particularly births, are correlated with a sharp decrease in women's participation in continuing education. This finding probably refers to the unequal distribution of parental responsibility between the sexes (RICROCH, 2012), but also to the lower availability of women during periods of pregnancy or maternity leave.

If we take a look at participation in company training, we note that the negative correlation between childbirth and access to education for women is higher for those with a higher education diploma (odds ratio of 0.53 ) than for those with a baccalauréat degree or lower (odds ratio of 0.63 ). An explanation for this result can be found in the work of FOURNIER (2009) on women employees. The likelihood of reorganising one's life for education increases, all else being equal, with the level of the diploma: the arrival of a child generates important reorganisations that can subsequently affect the most highly qualified women more than the least educated. It is also possible that this result reflects the tendency of women with higher levels of education to postpone their educational projects to a time when parental constraints are not as tight. Our estimates show for instance that children's exit from early childhood is associated with a greater likelihood of participation in company training, but only for graduates of higher education. Children's entry into primary school can indeed constitute an opportunity: it facilitates an easing of parental tasks and frees up time. For men, our estimates show that the arrival of a child in the household is not correlated with the probability of participating in company training. Only the exit from early childhood is associated with greater access to education: for the most highly educated men who maintain their activity in order to ensure their role as primary income earner, children's

37. It is nevertheless necessary to treat these interpretations with caution, in particular regarding the importance of the odds ratio. In reality men who take part in education offered by employment agencies and obtain custody of their children upon a break-up make up only a very small part of our sample $(0.03 \%)$. 
TABLE 3 - Changes Related to the Parental Situation and Access to Company Training during the 15 Months of Interviews (Results from Binomial Logistic Regressions ${ }^{(1)}$ )

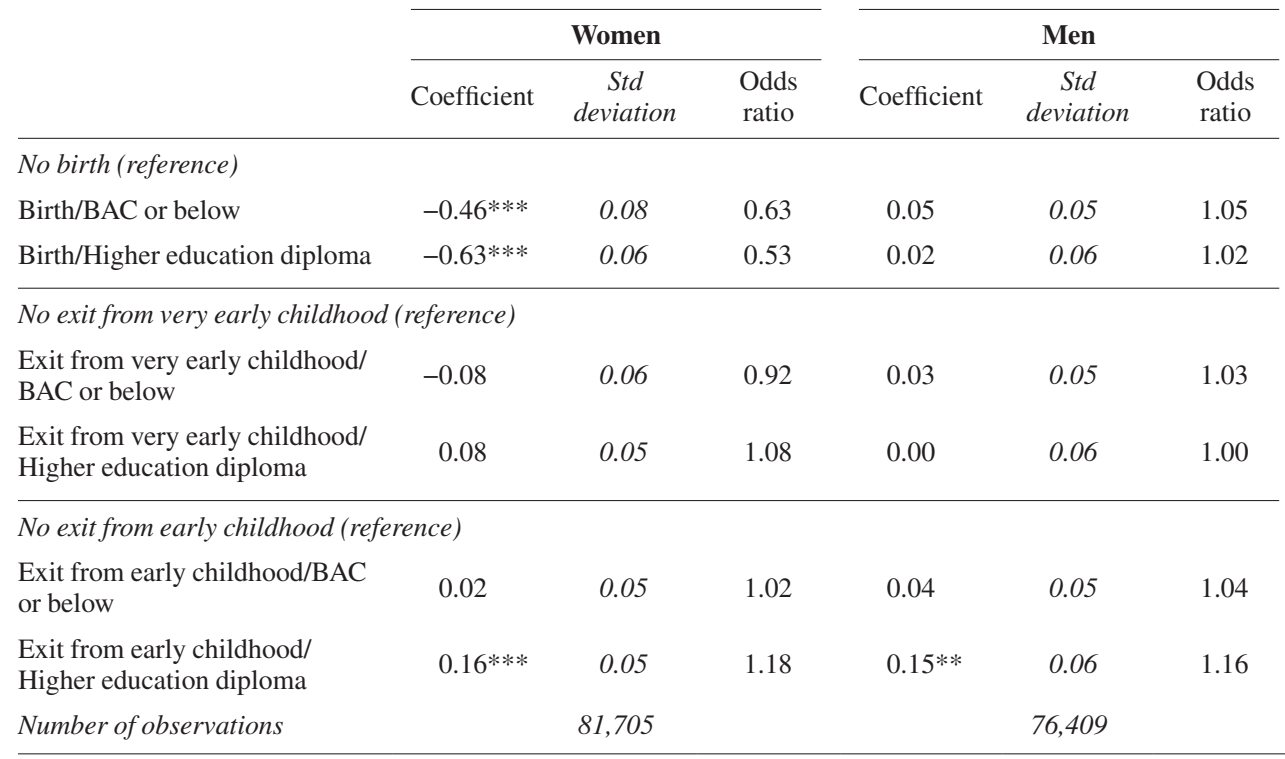

*** significant at the $1 \%$ threshold; ** significant at the 5\% threshold; * significant at the $10 \%$ threshold.

${ }^{(1)}$ The results of these estimates are available upon request from the author.

Interpretation: Beyond the effects of the control variables, women with a higher education who experience birth see their probability of access to company training reduced (odds ratio of 0.53 ).

Control variables introduced into the estimate: age, level of education, employment status, SOC, sector of activity, size of establishment, occupational mobility, country of birth, regional unemployment rate, family situation, and changes related to the conjugal situation. Field: Individuals who have finished initial education for more than one year.

Source: Emploi en continu surveys, 2003-2012, author's calculations.

entry into primary school provides an opportunity to increase (again) their level of human capital, in so far as they face fewer domestic constraints.

For the same reasons as above, the results for education offered by an employment agency differ from those for company training. For women, we note that the "birth" event is again negatively correlated with participation in education. The arrival of a child in particular constrains the trajectories of women who are out of work and can discourage them from presenting themselves in the labour market (PAILHÉ, SOLAZ, 2007): they are then likely to forego training offered by an employment agency. It should be noted, however, that the level of education does not act in the same direction as for company training. The decrease in the probability of taking part in education that occurs in tandem with a birth is less significant for women who are out of work with a higher education (odds ratio 0.2 ) than it is for those with a baccalauréat or less (odds ratio 0.15). These correlations reflect the idea that among unemployed women, the most educated have a stronger tendency to present themselves in the labour market following a birth than do those with a lower initial education. On the other hand, for 
TABLE 4 - Changes Related to the Parental Situation and Access to Education Offered by an Employment Agency during the 15 Months of Interviews (Results from Binomial logistic Regressions ${ }^{(1)}$ )

\begin{tabular}{lcc}
\hline & Women & \\
\hline Coefficient & $\begin{array}{c}\text { Std } \\
\text { deviation }\end{array}$ & $\begin{array}{l}\text { Odds } \\
\text { ratio }\end{array}$
\end{tabular}

\begin{tabular}{lcc}
\hline \multicolumn{3}{c}{ Men } \\
\hline Coefficient & $\begin{array}{c}\text { Std } \\
\text { deviation }\end{array}$ & $\begin{array}{l}\text { Odds } \\
\text { ratio }\end{array}$ \\
\hline
\end{tabular}

\section{No birth (reference)}

Birth/BAC or below

Birth/Higher education diploma

$$
\begin{aligned}
& -0.90 * * * \\
& -0.39 *
\end{aligned}
$$

0.15

0.41

0.11

0.14

1.11

0.20

0.68

$0.53 * *$

0.22

1.70

No exit from very early childhood (reference)

Exit from very early childhood/

BAC or below

$-0.10$

0.11

0.90

0.08

0.14

1.08

Exit from very early childhood/

Higher education diploma

$$
-0.02
$$

0.18

0.98

$-0.09$

0.26

0.92

No exit from early childhood (reference)

Exit from early childhood/BAC or below

$-0.17$

0.11

0.84

0.05

0.14

1.05

Exit from early childhood/

Higher education diploma

$-0.16$

0.21

0.85

$-0.38$

0.32

0.69

Number of observations

81,705

76,409

*** significant at the $1 \%$ threshold; ** significant at the 5\% threshold; * significant at the $10 \%$ threshold.

${ }^{(1)}$ The results of these estimates are available upon request from the author.

Interpretation: Beyond the effects of the control variables, women without a higher education who experience birth see their probability of access to education by an employment agency reduced (odds ratio of 0.41 ).

Control variables introduced into the estimate: age, level of education, employment status, SOC, sector of activity, size of establishment, occupational mobility, country of birth, regional unemployment rate, family situation, and changes related to the conjugal situation.

Field: Individuals who have finished initial education for more than one year.

Source: Emploi en continu surveys, 2003-2012, author's calculations.

men with a higher education Table 4 shows a positive relationship between the birth of a child and the probability of access to education offered by an employment agency: ${ }^{38}$ the men are thus seeking to fulfil their role as "primary income earner" (ANXO et al., 2007; Meurs, Ponthieux, 2000; Pailhé, Solaz, 2007) and turn to the education offered by an employment agency to return to the labour market and ensure greater financial resources for the household. Given the results obtained for company training and in light of the assumptions we have made, the positive link between the occurrence of a birth and access to education seems to concern only unemployed men and those with a higher education.

Our estimates show significant associations between the occurrence of family events and the likelihood of access to further education that differ by gender and by type of education. As suggested by the life course approach, taking family events into account is therefore important in understanding inequalities in access to education

38. Here we once again find the effect highlighted by FRIEBEL (2008) in the case of Germany. 
and -more generally- existing inequalities in the labour market. From this point of view, our analysis is in line with and complements studies which, from the life course perspective, highlight the determining role of changes in individuals' family situation on the heterogeneity of professional trajectories (ANXo et al., 2007).

\section{Can the Results of the Estimates Be Interpreted in Terms of Causality?}

The hypotheses that we have presented and the interpretations they have given rise point towards mechanisms that explain the causal impact of family changes on access to continuing education. But while the associations that we have highlighted are important, it is not possible to directly interpret the coefficients of our estimates in a causal way: our regressions allow us to identify whether the family events have a significant correlation with further education, but the method chosen does not allow us to conclude that it is the changes in the family situation that "cause" the education.

Indeed, our estimates may first of all be subject to endogeneity problems linked to the existence of inverse causalities: while the occurrence of a family event can influence access to vocational training, the reciprocal effect is also conceivable. The estimated coefficients are therefore likely to reflect the mutual influences between the explanatory variable and the explained variable. To deal with this difficulty, it would be necessary to be able to identify precisely the dates on which individuals make their decisions about education and about their family. This approach seems impracticable in light of the events we are analysing. Indeed, with the exception of forming a couple, which can be the result of an "unforeseen" encounter, break-ups, births, children's entry into school and further education too are probably more in the nature of people's expectations. Thus, even if we have precise information about individual calendars, it is not clear that exploiting the chronology of people's individual statuses would permit better control of biases related to reverse causality, including by integrating delayed variables or by being limited to family changes that take place upstream of a possible participation in an education programme: for example, even if education precedes a separation, it may reflect an individual's willingness to take part in education in order to better be prepared for the "single" life (becoming financially independent, etc.).

Despite this limitation, it is possible to consider the conditions in which our results might be interpretable from the point of view of the causal relations that we evoked in our hypotheses. To do this, in contrast to what we have done previously we need to question the potential effects of continuing education on family events as well as how likely or unlikely they may be. Several mechanisms can be described in terms of our results. First of all, with regard to couple formation, the education might take place before a job is taken, enabling the individual to meet his or her future partner in the workplace, which is consistent with the coefficients in Table 1 on company training. Just as has been observed for initial education, ${ }^{39}$ continuing education, especially

39. Isabelle RoBERT-BobÉE and Magali MAZUy (2005) show that continuing initial education delays couple formation. 
when it refers to lengthy periods, could on the contrary leave little time to form a couple, which would explain the results of Table 2 for men (education offered by an employment agency). To verify these inverse causalities, ${ }^{40}$ we have restricted ourselves to education that takes place after a couple formation: ${ }^{41}$ the effects that we obtain remain significant, which is in line with our hypotheses. As far as a break-up is concerned, taking part in education can boost people's financial independence and lead them to leave an unhappy situation. This mechanism could explain the coefficients reported in Table 2 (education by employment agencies). Nevertheless, in order to capture this "emancipation" effect using our data, the gains from education would have to be immediate and sufficiently substantial in the short term for the individuals to leave their unhappy situation: the window of 15 months that we have used may seem in this light to be too short to identify this type of behaviour. Finally, with regard to parental events, the biases linked to the phenomena of inverse causality also seem limited. Indeed, it seems unlikely, at least in the short term, that continuing education could "cause" either women to renounce their desire for children or men to want to have them. Similarly, children's entry into primary school cannot be the direct consequence of participation in continuing education, since it depends above all on legal arrangements.

Beyond the problems of inverse causation, our estimates may also be affected by biases related to the fact that some unobserved characteristics affect both access to continuing education and family events: if this is the case, then the coefficients estimated confuse the causal impact of the events and the effect of these unobservable characteristics. Several characteristics that can influence both family behaviour and participation in continuing education can be identified. As is often highlighted in the literature on the supply of labour (Moschion, 2009), first it is conceivable that some of the women who decide to have a child are also those who prefer to remain inactive and do not feel any need for education. Likewise, individuals who are separated might have a greater appetite for "change" (professional, family, etc.), which may lead them to seek greater mobility in the labour market, accompanied where necessary by further education. Finally, on the basis of studies on the links between professional status and conjugal status (EKERT-JAFFÉ, SOLAZ, 2001; NEZOSI, 2000), it may be that individuals (especially men) who are selected for company training programmes have particular characteristics (stability in the labour market, specific skills, etc.) that also make them attractive on the marriage market, ${ }^{42}$ which would then bias the coefficients associated with couple formation.

To correct these biases, panel analyses could be used, introducing, for example, individual fixed effects in order to neutralise the influence of unobservable characteristics.

\footnotetext{
40. This verification was carried out only for couple formation insofar as this is an event that leaves less room for the effects of anticipation than a break-up or the arrival of a new child in the household.

41. More precisely, we considered only the couple formations that took place in the first nine months of the observation window and the education taking place over the last six months.

42. This bias in attractiveness would in particular help to explain the negative sign of couple formation for men with respect to education offered by employment agencies (see above).
} 
Nevertheless, in our database, few individuals are affected by family events (see above), which is an important limitation when taking into account unobservables in the panel analyses (WOOLDRIDGE, 2002). ${ }^{43}$ Our general approach has been to carry out very fine controls on the professional characteristics (including seniority, type of contract, sector of activity, the size of the firm and mobility). While this cannot eliminate all biases, these numerous controls, which may reflect individual preferences and characteristics, are very likely to decrease the disturbance associated with any unobservables in a non-negligible way. Furthermore, the separate estimates and cross-tabulations that we have carried out also limit potential biases. For example, concerning break-ups, the interpretation in terms of "appetite for change" seems unlikely given that the role of this event is primarily conditional on the custody of children. Similarly, the biases of attractiveness on couple formation potentially concern only the men: for company training, however, it can be seen that couple formation is associated with a positive coefficient regardless of the gender. Finally, the variables relating to the care of children by the primary school certainly leave little room for unobserved characteristics insofar as the schooling of children from the age of 6 is a legal obligation.

In order to deepen our analysis of the causal effect of family events, qualitative field surveys (interviews with individuals and employers) need to be developed which, in line with the FRIEBEL model (2008), would make it possible to identify more precisely the decision-making processes at work and the channels through which family changes influence participation in continuing education. Nevertheless, in concluding this discussion, it seems that the possible presence of the various aforementioned biases does not call into question our conclusions. In this sense, our results show that participation in continuing education and family changes are closely linked within an individual's career. Thus, beyond the family situation alone, our analysis calls for greater consideration of family and professional projects and their interactions in the implementation of continuing education policies. This attention to the family dimension in the management and promotion of continuing education could take the form of personalised interviews that aim, in particular in the framework of the new personal education account (CPF), to accompany individuals throughout their "life course".

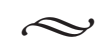

Using the 2003-2012 EECs, we have shown that changes in the family situation are associated, "all else being equal", with access to continuing education. This observation is consistent with the hypotheses we have put forward: family events contribute to modifying the financial and temporal constraints affecting individuals and can therefore have an impact on their educational activities. Our results show sharp inequalities between men and women: the main reasons for this seem to be

43. Moreover, as we have pointed out, given the potential existence of anticipatory effects these panel analyses do not solve the problems linked with inverse causality. 
the persistence of the "Monsieur Breadwinner" model, the unequal division of the domestic burden between sexes and the difficulties that women encounter in reconciling work and family life. Specifically, our estimates indicate that the break-up of a couple is negatively correlated with the likelihood of participating in company training for women who have custody of their children, and positively for men who do not retain custody. Insofar as it is the former who are mostly entrusted with the care of the children (RÉGNIER-LOILIER, 2013), this result suggests that break-ups affect participation in continuing education by increasing the temporal constraints on women and reducing those on men. However, these gender inequalities appear to be much more nuanced in terms of education offered by employment agencies. In this regard, it seems that it is less the distribution of the children's custody that counts and more the partner's situation at the time of the break-up: whatever the gender, a positive link can be seen between access to education and the break-up if the latter takes place with a partner who has a job. This implies that jobless individuals who separate are encouraged to return to employment in order to maintain their standard of living and, at the same time, undertake training to support this re-entry into the labour market. The asymmetry between women and men in relation to family events is much more pronounced with regard to births. The new arrival of a child in the household is associated with a significant decrease in the likelihood of women accessing company training, while we do not observe a significant link for men. Moreover, by differentiating these correlations according to the individual's level of education, two additional conclusions can be drawn. First, while the access to company training of women with a higher education falls significantly more than for women with a baccalauréat degree or less in the event of childbirth, their probability of taking part in continuing education increases from the time when the primary school takes charge of the children: this amounts to a catch-up effect by women with a higher level of education or to their postponing their educational projects. Finally, it appears that births are associated with a greater likelihood of accessing the education offered by an employment agency for men with a higher education, which may reflect, when this event occurs, their desire to fulfill their role as "primary income earner".

The results presented here obviously point out the need for further work to identify "purely" causal relationships. Nevertheless, they already call for taking into account determinants that have hitherto been excluded from the field of policy, by showing that it is legitimate to situate family events amidst the array of factors involved in access to education. This is all the more important as the events we analysed most often occur in the middle of the career, that is, when the probability of taking part in education is highest (BLASCO et al., 2009). The relationship with participation in continuing education is therefore likely to generate polarisations between the trajectories of individuals through the phenomenon of accumulation.

While the introduction of the personal education account (CPF) is a step forward in attaching the right to continuing education to people rather than to the employment contract, our results emphasise the central importance of support policies (follow-up 
of individuals, advice, etc.) in the promotion of lifelong learning (GAUTIÉ, PEREZ, 2010). These policies constitute the main lever for guiding individuals in constructing their educational pathway while taking into account the personal events that they face during their careers. These policies are an essential and customisable tool that everyone involved in education needs to take into account more than ever before to combat inequalities in access.

\section{REFERENCES:}

AnXo, D., ERHEL, C. (2008). «Irréversibilité du temps, réversibilité des choix ? Les fondements des "marchés transitionnels" en termes de trajectoires de vie. » Revue française de socioéconomie, 1, 199-219.

Anxo, D., Fagan, C., Cebrian, I. \& Moreno, G. (2007). "Patterns of Labour Market Integration in Europe-A life Course Perspective on Time Policies." Socio-Economic Review, 5(2), 233-260.

Barrère-Maurisson, M.-A., Minni, C., Rivier, S. (2001). « Le partage des temps pour les hommes et les femmes ou comment conjuguer travail rémunéré, non rémunéré et non-travail. » Premières Synthèses, 11.1. Paris: Direction de l'animation de la recherche, des études et des statistiques (Dares).

Beaumel, C., Pla, A. (2012). « Bilan démographique 2011. La fécondité reste élevée. » Insee Première, 1385.

Blasco, S., Le J. \& Monso, O. (2009). « Formation continue en entreprise et promotion sociale mythe ou réalité ? » In Insee, Formations et emploi, Insee références (pp. 27-42). Paris: Insee.

Bonnet, C., Solaz, A., AlgaVA, É. (2010). « Les changements professionnels en France autour de la séparation conjugale. » Population, 65(2), 273-308.

Butz, W. P., Torrey, B. B. (2006). "Some Frontiers in Social Science.” Science Magazine, 312(5782), 1898-1900.

Conseil de L'emploi, Des ReVenus et de la cohésion sociale (Cerc) (2006). « La France en transition. 1993-2005. » Rapport, no 7, Paris: La Documentation française.

Crocquey, E. (1995). « La formation professionnelle continue : des inégalités d'accès et des effets sur la carrière peu importants à court terme. » Travail et Emploi, 65, 61-68.

Cytermann, C., WanecQ, T. (2010). Les Politiques sociales : droit du travail, politiques de l'emploi et de la cohésion sociale. Paris: Presses universitaires de France.

Descamps, R. (2012). « Le DIF : la maturité modeste. » Bref du Céreq, 299-2.

DiRECTION DU BUDGet (2013). Projet de loi de finances pour 2014 (Jaune Budgétaire), Annexe sur la formation professionnelle. Paris: Ministère des Finances et des Comptes publics.

DUBAR, C. (2008). « Les changements possibles du système français de formation continue. » Formation emploi, 101, 167-182.

Dubar, C. (2004). La Formation professionnelle continue (5th edition). Paris: La Découverte. 
Dubois, J.-M., Fournier, C. (2014). « Les freins à la formation vus par les salariés. » Bref du Céreq, 323.

Ekert-JafFe, O., Solaz, A. (2001). "Unemployment, Marriage, and Cohabitation in France." The Journal of Socio-Economics, 30(1), 75-98.

Elder, G. H. Jr. (1998). "The Life Course as a Developmental Theory.” Child Development, 69(1), 1-12.

Elder, G. H. Jr. (1985). Life Course Dynamics: Trajectories and Transitions, 1968-1980. Ithaca: Cornell University Press.

EydouX, A., LeTABlier, M.-T. \& SYLLA, S. (2006). « La conciliation vie professionnelle et vie familiale de personnes pauvres ou précaires. » In Les Travaux de l'observatoire national de la pauvreté et de l'exclusion sociale (pp. 161-197). Paris: La Documentation française.

FLETCHER, C. (2002). « Formation continue à la française et système de laissez-faire britannique : quelles chances pour les femmes ? » Formation emploi, 78, 17-33.

FrIEBEL, H. (2008). "The Children of the Educational Expansion Era in Germany: Education and Further Training Participation in the Life-Course.” British Journal of Sociology of Education, 29(5), 479-492.

Fournier, C. (2001). « Hommes et femmes salariés face à la formation continue. » Bref, 179. Marseille: Céreq.

Fournier, C. (2008). « La formation va-t-elle à la formation ?» In J.-J. Paul, J. Rose (Eds.), Les Relations formation-emploi en 55 questions (pp. 114-119). Paris: Dunod.

Fournier, C., Sigot, J.-C. (2009). « Concilier vie familiale et formation continue, une affaire de femmes. »Bref, 262. Marseille: Céreq.

Gautié, J., Perez, C. (2010). «Les comptes individuels de formation : fondements et enseignements.» In F. Degrave, D. Desmette, É. Mangez, M. Nyssens \& P. Reman (Eds.), Transformations et innovations économiques et sociales en Europe : quelles sorties de crise? Regards interdisciplinaires (pp. 297-315). Louvain-la-Neuve: Presses universitaires de Louvain, « Cahiers du CIRTES », no 4.

Giele, J. Z., Elder, G. H. Jr. (1998). Methods of Life Course Research. Qualitative and Quantitative Approaches. Thousand Oaks (Calif.): Sage publications.

Gossiaux, S., Pommier, P. (2013). « La formation des adultes. Un accès plus fréquent pour les jeunes, les salariés des grandes entreprises et les plus diplômés. » Insee Première, 1468.

Greenhalgh, C., Stewart, M. (1987). "The Effects and Determinants of Training." Oxford Bulletin of Economics and Statistics, 49(2), 171-190.

Heckman, J. J., Smith, J. A. (1999). "The Pre-Program Earnings Dip and the Determinants of Participation in a Social Program: Implications for Simple Program Evaluation Strategies." The Economic Journal, 109(457), 313-348.

Hui, T. S., Smith, J. A. (2002). "The Determinants of Participation in Adult Education and Training in Canada.” MPRA Paper, 17998. 
Hutchison, E. D. (2011). “A Life Course Perspective.” In E. D. Hutchison et al., Dimensions of Human Behavior: the Changing Life Course (pp. 1-38). Los Angeles: Sage.

LAmbert, M., Marion-Vernoux, I. \& Sigot J.-C. (Eds.) (2009). Quand la formation continue : repères sur les pratiques de formation des employeurs et des salariés. Marseille: Céreq.

Maurice, M. (1989). « Méthode comparative et analyse sociétale. Les implications théoriques des comparaisons internationales. » Sociologie du travail, 2, 175-191.

MÉdA, D. WierinK, M. \& SimOn, M.-O. (2003). « Pourquoi certaines femmes s'arrêtent-elles de travailler à la naissance d'un enfant ? » Premières informations, premières synthèses, 29.2. Paris: Dares.

Meurs, D., Ponthieux, S. (2000). «Une mesure de la discrimination dans l'écart de salaires entre hommes et femmes ? « Économie et statistique, 337-338, 135-158.

Moschion, J. (2012). « Concilier vie familiale et vie professionnelle. L'effet de la préscolarisation. » Revue économique, 63(2), 187-214.

Moschion, J. (2009). « Offre de travail des mères en France : l'effet causal du passage de deux à trois enfants. » Économie et statistique, 422, 51-78.

Nezosi, G. (2000). «Quelques éclairages sur les conséquences du chômage sur la famille. » Recherches et prévisions, 60, 5-16.

Pailhé, A., Solaz, A. (2007). «Inflexions des trajectoires professionnelles des hommes et des femmes après la naissance d'enfants. » Recherches et prévisions, 90, 5-16.

Perez, C., Thomas, G. (2005). « Trajectoires d'emplois précaires et formation continue. » Économie et statistique, 388-389, 107-127.

RÉGNIER-LOILIER, A. (2013). «Quand la séparation des parents s'accompagne d'une rupture du lien entre le père et l'enfant. » Population et sociétés, 500. Paris: Institut national d'études démographiques (Ined).

Ricroch, L. (2012). «En 25 ans, moins de tâches domestiques pour les femmes, l'écart de situation avec les hommes se réduit. » In Insee, Femmes et hommes. Regards sur la parité, Insee références (pp. 67-80). Paris: Insee.

Robert-Bobée, I., Mazuy, M. (2005). « Calendriers de constitution des familles et âge de fin d'études. » In C. Lefevre, A. Filhon (Eds.), Histoires de familles, histoires familiales : les résultats de l'enquête Famille de 1999 (pp. 175-200). Paris: Ined.

SeILlier, B. (2007). « Rapport d'information fait au nom de la mission commune d'information sur le fonctionnement des dispositifs de formation professionnelle. » Les Rapports du Sénat, 365 .

Settersten, R. A. Jr, Mayer, K. U. (1997). “The Measurement of Age, Age Structuring and the Life Course." Annual Review of Sociology, 23, 233-261.

ThÉVEnon, O. (2009). «L'augmentation de l'activité des femmes en Europe : progrès de la conciliation ou polarisation des comportements ? » Population, 64(2), 263-303.

Wooldridge, J. M. (2002). Econometric Analysis of Cross Section and Panel Data. Cambridge (Mass.): MIT Press. 


\section{APPENDIX}

\section{TABLE A1 - Breakdown of Individual Characteristics among the Observations Conserved and Rejected}

\begin{tabular}{|c|c|c|}
\hline & Observations kept & Observations rejected \\
\hline \multicolumn{3}{|l|}{ Socio-Occupational Category (SOC) } \\
\hline Farmer-operators & 2.54 & 1.33 \\
\hline Artisans, shopkeepers and business heads & 6.05 & 5.82 \\
\hline Executives and higher intellectual professions & 14.90 & 16.47 \\
\hline Intermediary professions & 22.77 & 22.94 \\
\hline White-collar employees & 29.11 & 28.75 \\
\hline Blue-collar employees & 23.31 & 22.68 \\
\hline Unemployed who have never worked & 1.12 & 1.91 \\
\hline
\end{tabular}

\section{Diploma level}

Higher education diploma +2 years

$10.28 \quad 13.71$

French baccalauréat +2 years

French baccalauréat or other equivalent diploma

15.08

17.68

$\mathrm{CAP}, \mathrm{BEP}$ or equivalent pre-BAC vocational diploma

21.72

19.67

Middle school diploma

10.67

10.10

No diploma or CEP (primary education) level

33.26

28.55

\section{Seniority in the company}

Less than one year

From 1 year to less than 5 years

From 5 years to less than 10 years

\section{Age}

From 15 to 29

From 30 to 39

15.61

18.84

From 40 to 49

18.26

16.49

From 50 to 59

17.99

14.52

60 or over

31.10

22.09

\section{Family situation}

Single person household

16.75

19.88

Single-parent family

Couple without children

Couple with children

41.54

40.04

Complex households

3.56

4.38

\section{Gender}

Field: All individuals interviewed.

Source: Emploi en continu surveys, 2003-2012, author's calculations. 
TABLE A2 - Definitions of the "Type of Education" Variable in the EEC Series (Based on Year) and Rate of Access among those Educated

\begin{tabular}{|c|c|c|c|c|c|c|c|c|c|c|}
\hline $\begin{array}{r}\text { Year } \\
\text { Modality }\end{array}$ & 2003 & 2004 & 2005 & 2006 & 2007 & 2008 & 2009 & 2010 & 2011 & 2012 \\
\hline 1 & \multicolumn{2}{|c|}{ CIF } & \multicolumn{2}{|c|}{ CIF } & \multicolumn{6}{|c|}{ CIF } \\
\hline 2 & \multicolumn{2}{|c|}{$\begin{array}{l}\text { Education } \\
\text { combining } \\
\text { periods in } \\
\text { the company } \\
\text { and in the } \\
\text { training centre } \\
\text { (alternating } \\
\text { training } \\
\text { excluding } \\
\text { apprenticeships) }\end{array}$} & \multicolumn{2}{|c|}{$\begin{array}{l}\text { Training } \\
\text { proposed by the } \\
\text { employer }\end{array}$} & \multicolumn{6}{|c|}{ DIF } \\
\hline 3 & \multicolumn{2}{|c|}{$\begin{array}{l}\text { Education } \\
\text { proposed by the } \\
\text { employer }\end{array}$} & \multicolumn{2}{|c|}{$\begin{array}{l}\text { Education } \\
\text { proposed by an } \\
\text { employment } \\
\text { agency }\end{array}$} & \multicolumn{6}{|c|}{ Education proposed by the employer } \\
\hline 4 & \multicolumn{2}{|c|}{$\begin{array}{l}\text { Education } \\
\text { proposed by an } \\
\text { employment } \\
\text { agency }\end{array}$} & \multicolumn{2}{|c|}{$\begin{array}{l}\text { Education } \\
\text { followed on } \\
\text { own account } \\
\text { (including } \\
\text { renewal of } \\
\text { studies) }\end{array}$} & \multicolumn{6}{|c|}{$\begin{array}{c}\text { Education proposed by an employment } \\
\text { agency }\end{array}$} \\
\hline 5 & \multicolumn{2}{|c|}{$\begin{array}{l}\text { Education } \\
\text { followed on } \\
\text { own account } \\
\text { (including } \\
\text { renewal of } \\
\text { studies) }\end{array}$} & \multicolumn{2}{|c|}{-} & \multicolumn{6}{|c|}{$\begin{array}{l}\text { Education followed on own account } \\
\text { (including renewal of studies) }\end{array}$} \\
\hline 1 & 1.7 & 1.7 & 1.6 & 1.7 & 1.0 & 1.2 & 1.5 & 1.4 & 1.6 & 1.4 \\
\hline 2 & 4.7 & 3.9 & 61.9 & 61.6 & 3.5 & 4.7 & 5.2 & 4.6 & 4.5 & 3.9 \\
\hline 3 & 63.3 & 61.5 & 7.0 & 6.2 & 58.1 & 58.2 & 56.6 & 55.3 & 60.6 & 60.7 \\
\hline 4 & 5.1 & 5.5 & 29.6 & 30.5 & 6.2 & 5.6 & 6.9 & 7.0 & 6.8 & 7.0 \\
\hline 5 & 25.2 & 27.4 & & & 31.3 & 30.2 & 29.8 & 31.6 & 26.5 & 27.0 \\
\hline
\end{tabular}

Field: All individuals taking part in education (excluding initial education).

Source: Emploi en continu survey, 2003-2012, author's calculations. 
TABLE A3 - The “Conventional Determinants” of Continuing Education (Logistic Models)

\begin{tabular}{|c|c|c|c|}
\hline \multicolumn{2}{|c|}{ FENTR } & \multicolumn{2}{|c|}{ FPLAC } \\
\hline Women & Men & Women & Men \\
\hline
\end{tabular}

Coefficient Std deviation Coefficient Std deviation Coefficient Std deviation Coefficient Std deviation

\begin{tabular}{lrrrrrrr}
\hline Age & $0.09 * * *$ & 0.01 & $0.03 * * *$ & 0.01 & $-0.02 * * *$ & 0.00 & $-0.02 * * *$ \\
Age squared & $-0.0011 * * *$ & 0.0001 & $-0.0006 * * *$ & 0.0001 & & &
\end{tabular}

\section{Diploma}

Without diploma or equivalent (reference)

\begin{tabular}{|c|c|c|c|c|c|c|c|c|}
\hline $\begin{array}{l}\text { CAP/BEP } \\
\text { (pre-BAC) }\end{array}$ & $0.25^{* * *}$ & 0.03 & $0.20 * * *$ & 0.03 & $0.13 * *$ & 0.06 & 0.00 & 0.07 \\
\hline $\begin{array}{l}\text { General } \\
\text { baccalauréat }\end{array}$ & $0.36^{* * *}$ & 0.04 & $0.26 * * *$ & 0.04 & 0.10 & 0.09 & 0.17 & 0.12 \\
\hline $\begin{array}{l}\text { Legal capacity } \\
\text { certificate } \\
\text { (capacité en } \\
\text { droit) }\end{array}$ & 0.05 & 0.39 & 0.10 & 0.45 & 0.47 & 0.57 & 0.23 & 1.27 \\
\hline $\begin{array}{l}\text { Vocational } \\
\text { baccalauréat }\end{array}$ & $0.39 * * *$ & 0.06 & $0.42 * * *$ & 0.05 & 0.10 & 0.12 & 0.00 & 0.14 \\
\hline $\begin{array}{l}\text { Technological } \\
\text { baccalauréat }\end{array}$ & $0.54 * * *$ & 0.04 & $0.44 * * *$ & 0.05 & 0.10 & 0.11 & $0.37 * * *$ & 0.14 \\
\hline DEUG & $0.52 * * *$ & 0.07 & $0.37 * * *$ & 0.09 & 0.09 & 0.19 & -0.12 & 0.31 \\
\hline DUT/DEUST & $0.84 * * *$ & 0.07 & $0.57 * * *$ & 0.06 & -0.30 & 0.25 & $0.36^{*}$ & 0.19 \\
\hline BTS & $0.64 * * *$ & 0.04 & $0.49 * * *$ & 0.04 & 0.08 & 0.10 & 0.15 & 0.12 \\
\hline $\begin{array}{l}\text { Other higher } \\
\text { technical diploma }\end{array}$ & $0.57 * * *$ & 0.13 & $0.25 * *$ & 0.12 & 0.07 & 0.34 & -0.61 & 0.54 \\
\hline $\begin{array}{l}\text { Paramedical } \\
\text { diploma }\end{array}$ & $0.72 * * *$ & 0.05 & $0.21 * *$ & 0.09 & $-0.62 * * *$ & 0.22 & -0.48 & 0.62 \\
\hline Licence & $0.37 * * *$ & 0.05 & $0.44 * * *$ & 0.06 & -0.23 & 0.15 & -0.23 & 0.23 \\
\hline $\begin{array}{l}\text { Other BAC+3 } \\
\text { diploma }\end{array}$ & $0.39 * * *$ & 0.09 & $0.27 * * *$ & 0.08 & 0.03 & 0.25 & $-1.12 * *$ & 0.47 \\
\hline $\begin{array}{l}\text { Master's } \\
\text { (maîtrise) }\end{array}$ & $0.49 * * *$ & 0.05 & $0.26^{* * *}$ & 0.06 & -0.23 & 0.17 & 0.06 & 0.22 \\
\hline DEA & $0.70 * * *$ & 0.09 & $0.16^{*}$ & 0.10 & $-1.43 * *$ & 0.58 & 0.29 & 0.35 \\
\hline DESS & $0.63^{* * *}$ & 0.06 & $0.44 * * *$ & 0.07 & -0.20 & 0.22 & -0.04 & 0.26 \\
\hline Business school & $0.56^{* * *}$ & 0.11 & $0.23 * *$ & 0.11 & 0.18 & 0.39 & -0.91 & 0.58 \\
\hline $\begin{array}{l}\text { Engineering } \\
\text { school }\end{array}$ & $0.78 * * *$ & 0.10 & $0.56^{* * *}$ & 0.06 & -0.21 & 0.41 & -0.04 & 0.24 \\
\hline $\begin{array}{l}\text { Doctorate (excl } \\
\text { medicine) }\end{array}$ & $0.85^{* * *}$ & 0.09 & $0.46^{* * *}$ & 0.10 & -0.50 & 0.45 & -0.11 & 0.64 \\
\hline $\begin{array}{l}\text { Doctorate (in } \\
\text { medicine) }\end{array}$ & -0.03 & 0.13 & 0.004 & 0.11 & -0.48 & 0.54 & -1.22 & 0.91 \\
\hline
\end{tabular}




\begin{tabular}{|c|c|c|c|}
\hline \multicolumn{2}{|c|}{ FENTR } & \multicolumn{2}{|c|}{ FPLAC } \\
\hline Women & Men & Women & Men \\
\hline
\end{tabular}

\section{Professional situation}

In work (5 years and more) full-time CDI (contrat à durée indéterminée - open-ended contract) (reference)

In work (5 years and more), parttime CDI

$-0.10 * * * \quad 0.04$

0.10

$-0.77 * * *$

0.16

0.24

0.33

In work (5 years and more), fulltime CDD

$$
\begin{array}{llllllll}
0.15^{* * *} & 0.03 & -0.08^{* *} & 0.04 & -1.36^{* * *} & 0.17 & -1.80 * * * & 0.22
\end{array}
$$

In work (5 years and more), parttime CDD

$\begin{array}{llllllll}0.10 * * & 0.04 & -0.60 * * * & 0.13 & -1.13 * * * & 0.25 & -3.19 * & 1.89\end{array}$

In work (less than 5 years), full-time CDI

$\begin{array}{llllllll}0.10 * * * & 0.03 & -0.07 * * * & 0.03 & -0.67 * * * & 0.12 & -0.56 * * * & 0.10\end{array}$

In work (less than 5 years), parttime CDI

$\begin{array}{lll}-0.23 * * * & 0.05 & -0.65 * * *\end{array}$

In work (less than 5 years), full-time CDD

$0.16^{* * *} \quad 0.04 \quad-0.10^{* *}$

$0.13-0.33 * *$

0.13

0.13

0.28

In work (less than

5 years), parttime CDD

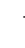

Not in work (less than 1 year)

$$
-0.14 * * \quad 0.06
$$

$-0.69 * * * \quad 0.12$

0.19

0.12

$0.51 * * *$

0.20

Not in work

(1 year to less

$\begin{array}{llll}-1.74 * * * & 0.07 & -1.55 * * * & 0.08\end{array}$

$1.71 * * * \quad 0.07$

$1.65^{* * *}$

0.08 than 2 years)

$$
-1.82 * * * \quad 0.09
$$

$$
-1.82 * * *
$$

0.13

$1.34 * * * \quad 0.08$

$1.70^{* * *}$

0.09

Not in work

(2 years to less

$-2.13 * * *$

0.12

$-2.47 * * * \quad 0.25$

$1.22 * * *$

0.10

$1.81 * * *$

0.12 than 3 years)

Not in work (more than 3 years)

$-2.69 * * * \quad 0.09$

$-2.95 * * *$

0.19

$0.67 * * *$

0.07

$1.07 * * *$

0.11

\section{SOC}

Executive/ manager

Intermediary profession

$0.23 * * * \quad 0.04 \quad 0.09 * *$

0.04

$-0.27 * *$

0.13

$-0.15$

0.14

White-collar employee (reference)

Blue-collar worker

$0.30 * * * \quad 0.03$

$0.24 * * *$

0.03

$-0.04$

0.07

$-0.15$

0.11

Other or not filled

in

$$
-0.59 * * * \quad 0.04
$$

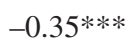

0.03

$-0.11$

0.08

0.09

0.09

$-0.92^{* * *} \quad 0.07$
Construction (reference)
$0.41 * * * \quad 0.12$

\section{Sector of activity}

Manufacturing and Construction (reference)

Energy

$$
0.41 * * * \quad 0.12
$$

$0.68 * * * \quad 0.06$

0.37

0.34

0.01

0.28 


Women Men Women Men

Coefficient Std deviation Coefficient Std deviation Coefficient Std deviation Coefficient Std deviation

\begin{tabular}{lrrrrrrrr}
\hline $\begin{array}{l}\text { Finance and real } \\
\text { estate }\end{array}$ & $0.51 * * *$ & 0.05 & $0.42 * * *$ & 0.05 & $-0.52 * * *$ & 0.16 & 0.12 & 0.18 \\
Business services & $0.14 * * *$ & 0.04 & 0.02 & 0.03 & -0.13 & 0.10 & $0.23 * * *$ & 0.09 \\
$\begin{array}{l}\text { Personal services } \\
\text { Public sector }\end{array}$ & $-0.30 * * *$ & 0.05 & $-0.57 * * *$ & 0.05 & -0.10 & 0.09 & $-0.31 * *$ & 0.12 \\
$\begin{array}{l}\text { Other- } \\
\begin{array}{l}\text { agriculture, } \\
\text { commerce }\end{array}\end{array}$ & $-0.13 * * * *$ & 0.04 & $0.28 * * *$ & 0.04 & -0.09 & 0.08 & 0.00 & 0.11 \\
\hline
\end{tabular}

\section{Size of establishment}

10 to 49

employees

$-0.44$

$0.03 \quad-0.76$

0.04

$0.22 * *$

0.10

0.15

0.11

50 to 499

employees

$$
-0.19
$$

$0.03 \quad-0.44$

0.03

$0.19 *$

0.10

0.14

0.11

$-0.04 \quad 0.03$

$-0.13$

0.03

$-0.09$

0.10

0.10

0.10

More than 500 employees (reference)

Undetermined or not filled in
$-1.13$
0.04

$-0.92$

0.04

0.17

0.10

0.02

0.11

\section{Occupational mobility during the 15 months}

Change of
position

Change of employer

Renewal of work

Loss of job

0.38

0.05

0.43

0.04

$-0.01$

0.12

0.14

$0.11-0.40$

$-0.19$

0.14

0.03

0.79

0.07

$-1.34$

0.06

0.07

$-0.09$

1.43

0.07

$-0.09$

0.06

1.67

0.08

\section{Country of birth}

France

Foreign

$-0.41$

0.04

$-0.44$

0.04

0.35

0.06

$-0.02$

0.08

\section{Regional}

\section{unemployment}

$-0.05$

0.01

$-0.03$

0.01

0.05

0.02

0.02

0.02

\section{Family situation}

Single childless (reference)

Single with child $\quad-0.05$

0.04

0.17

0.07

0.13

0.08

0.29

0.19

In couple w/o

$$
-0.13
$$

0.03

0.10

0.03

$-0.19$

0.08

$-0.01$

0.08

In couple with child

$-0.06 \quad 0.03$

0.19

0.03

$-0.36$

0.07

$-0.07$

0.07

$* * *$ significant at the $1 \%$ threshold, $* *$ significant at the $5 \%$ threshold, * significant at the $10 \%$ threshold. Field: Individuals who have finished initial education for more than one year.

Source: Emploi en continu interviews, 2003-2012, author's calculations. 